Journal of Business and Management Research

ISSN: 2382-5219(Print); 2467-9267(Online)

July 2017, Vol.2, No.1 \& 2, pp.33-51

(c) 2017 Kathmandu University

School of Management

DOI: http://dx.doi.org/10.3126/jbmr.v2i1-2.18150

\title{
Workplace Spirituality and Employee Attitudes: Moderating Role of Organizational Politics
}

\author{
Arjun Kumar Shrestha* \\ School of Management, Kathmandu University, Lalitpur, Nepal
}

\begin{abstract}
There is growing interest in examining the influence of workplace spirituality (WPS) on employee attitudes. However, there is still lack of studies that examine the relationships between WPS and employee attitudes and moderating effect of other variables on these relationships. This study examined the relationships between WPS and two job attitude variables - job satisfaction and job involvement. It also examined the moderating effect of perceptions of organizational politics (POP) on these relationships. Survey questionnaire was used to collect data from 500 employees working in two Nepali organizations, of which 480 questionnaires were used for further analysis. Structural equation modeling and multiple moderated regression analyses were used to test the hypothesized relationships. Results indicated that WPS is significantly positively related to job satisfaction and job involvement and POP moderates the relationship between WPS and job involvement. Research implications are discussed and limitations of the study are highlighted.
\end{abstract}

Keywords: Job involvement, job satisfaction, perceptions of organizational politics, workplace spirituality

\section{Introduction}

Spirituality at workplace has emerged as a movement in the workplaces and as an important construct in academia during 1990 s and early $21^{\text {st }}$ century. Its popularity is largely due to the economic downturn and demoralized and stressed workers as a result of introduction of new technologies in the production sector (Dirkx, 2013). This argument is further supported by Standifer, Evans, and Dong (2010) as they point to the fact that the upsurge of attention received by this construct in organizational behavior literature is due to increased competition, downsizing, and work becoming a primary source of community and identity of workers. Furthermore, Ashar and lane-Maher (2004) argue that at the advent of $21^{\text {st }}$ century, businesses are experiencing a paradigm shift - from the machine age or mechanical paradigm to a new paradigm that acknowledges that a company's competitive advantage resides in its human capital. They also suggest that bestowing on human capital is best achieved by incorporating spirituality into the workplace.

* Author Email: arjun@kusom.edu.np 
After the recognition of workplace spirituality (WPS) as an analytically distinct construct, there is growing interest among the scholarly community to empirically examine the linkages between WPS and different individual and organization level outcomes (e.g., Faro Albuquerque, Campos Cunha, Dias Martins, \& Brito Sá, 2014; Indratono \& Wulandari, 2014; Milliman, Czaplewski \& Ferguson, 2003; Rego \& Cunha, 2007). Daniel (2015) argues that despite the attempts made by previous scholars, there is still lack of studies investigating the influence of WPS on employee outcomes. However, lack of consensus among scholars in defining WPS and the use of markedly different scales with different dimensions for capturing WPS by previous studies make it difficult to draw definite conclusions regarding WPS - outcomes relationships. On the other hand, many authors in the recent past have proposed different conceptual models linking WPS to different outcome variables (e.g., Byrne, Morton, \& Dahling, 2011; Lee, Lovelac, \& Manz, 2014; Saks, 2011; Word, 2012), which need to be empirically tested.

As there is lack of studies investigating the impact of different factors on the relationships between WPS and outcomes, little is known about how other individual and organizational factors influence the impact of WPS on employee attitudes. Petchsawang and Duchon (2009), after developing a scale for measuring WPS in an eastern context, showed a need for additional empirical work to determine the connection between WPS and work outcomes. Word (2012) specifically highlighted a need to understand the association between WPS and job involvement as well as a need to investigate how the individual and organizational factors influence the impact of spirituality on job involvement. This call largely remains unaddressed. On the other hand, Lee et al. (2014) proposed that WPS could affect job satisfaction through ethical climate and workplace spirituality values such as respect, humanism, and integrity, which also need to be empirically tested.

Several studies have recognized that employees' perceptions of organizational politics (POP) are one of the important variables that negatively influence employee outcomes (e.g., Miller, Rutherford, \& Kolodinsky, 2008). In a politically charged organizational environment, employees are not treated as equal - some employees will benefit and others will suffer because POP are appraised as threatening aspects of organizational life (Rosen, Harris, \& Kacmar, 2009), whereas WPS refrains from such bias (Marques, 2010). Many studies have found the moderating effect of POP on the relationships between employee attitudes and their antecedents. For example, Shrestha and Mishra (2015) found that POP moderates the relationships between some dimensions of public service motivation and job satisfaction. Similarly, another study by Shrestha and Baniya (2016) showed that POP moderates the relationship between emotional intelligence and job satisfaction. However, the impact of POP on the relationships between WPS and employee attitudes has not been fully explored yet. This study intended to contribute to literature in WPS and employee attitudes in two different ways. First, it examined the direct effect of WPS on employees' job satisfaction and job involvement. Second, it assessed the moderating effect of POP on the relationship between WPS and employee attitudes - job satisfaction and job involvement.

\section{Literature Review and Research Hypotheses}

\section{Workplace Spirituality}

Scholarly endeavors to integrate spirituality into organizational context with the argument that spirituality not only influences individuals but also significantly affects organizational and managerial fields led to the emergence of new field of inquiry called WPS (Sheng \& Chen, 2012). In the literature, 
it is also synonymously called as spirituality at work, organizational spirituality, spirit at work, spirituality in business, etc. However, it should be noted that WPS is not limited to any formal religious tradition (Fagley \& Adler, 2012), rather it focuses on individual and organizational values and practices (Lee, Lovelace, \& Manz, 2014). Many scholars argue that the major causes of increased attention toward WPS are the changing work and life style, rise of self -exploration, and a growing trend to study life meaning and values by organization scholars (Sheng \& Chen, 2012). Thaker (2009) also posits that life's demand extends beyond the materialistic aspects, and there is a need to address spiritual aspect of individuals so as to achieve better results in an organizational setting.

WPS is a multi-dimensional construct that encompasses the individual, the organization, and the interactions of individuals within organization (Lee et al., 2014). At the individual level, it refers to a workplace where employees can feel a sense of community among their co-workers and other people associated with their organization; discover their meaning and purpose in life through their work; and find an alignment between their personal values with the values of the organization (Duchon \& Plowman, 2005). At the organizational level, it is reflected through the organization's policies and practices, which recognizes that employees have an inner life and a desire to find their work meaningful and provide a context for spiritual growth of the employees (Duchon \& Plowman, 2005).

\section{Workplace Spirituality Definitions}

Numerous definitions of WPS are found in literature. These definitions, as Pawar (2008) posits, broadly fall within two categories - (1) organization's facilitation of employee experience of spirituality at work (organizational aspect of spirituality) and (2) employee experience of spirituality at work. For example, Giacalone and Jurkiewicz's (2003) definition of workplace spirituality, "a framework of organizational values evidenced in the culture of organization that promotes employees' experience of transcendence through the work process, facilitating their sense of being connected to others in a way that provides feelings of connectedness and joy" (p. 13) falls within the first category of definition. On the other hand, Milliman et al.'s (2003) definition which views WPS as "an employee's experiencing sense of meaning at work, sense of connectedness with others at work, and an experience of alignment with the organization's mission and purpose" (p. 429-430), is consistent with the second category of definition.

Petchsawang and Duchon. (2009), while developing a scale for capturing WPS in the Eastern context, defined it as "having compassion towards others, experiencing a mindful inner consciousness in the pursuit of meaningful work that enables transcendence" (p. 465). Other definitions often cited in literature include the definitions put forward by Ashmos and Duchon (2000) and Kinjerski and Skrypneck (2004). Ashmos and Duchon (2000) defined WPS as "the recognition that employees have an inner life that nourishes and is nourished by meaningful work that takes place in the context of community" (p. 137). Kinjerski and Skrypneck (2004) define it as " a term that describes the experience of employees who are passionate about and energized by their work, find meaning and purpose in their work, feel that they can express their complete selves at work, and feel connected to those with whom they work" (p. 37).

The definitions presented above clearly suggest that although there is no one agreed-upon conceptualization, key dimensions have started emerging in the scholarly works. The key dimensions are: meaning and purpose of one's work (meaningful work), sense of community or connectedness within the work context, alignment between personal and organizational values, and transcendence 
(connection to the higher self through work). Dimensions of WPS are explored further in the following section.

\section{Workplace Spirituality Dimensions}

As WPS has been defined in many ways and there is little consensus over the meaning of WPS (Saks, 2011), scholars associate it with a number of key dimensions such as sense of connection with oneself, others, and workplace (Mitroff \& Denton, 1999), 'sense of inner life', 'meaningful work' and 'community' (Ashmos \& Duchon, 2000), 'organizational norms', 'innerself', 'connectedness', and 'personal fulfillment' (Pawar, 2009). Similarly, Kolodinsky, Giacalone, and Jurkiewicz (2008) proposed 'organizational norms', 'connectedness', and 'alignment with organizational value' as the dimensions of WPS. On the other hand, Liu and Robertson (2011) came up with three dimensions 'interconnection with a higher power', 'interconnection with human beings', and 'interconnection with nature and all living things'. Srirangarajan and Bhaskar (2011), while presenting key dimensions of spirituality at work from an Indian (Eastern) perspective, listed 15 different dimensions of WPS. Nonetheless, review of different definitions found in literature suggest that the common dimensions of WPS are 'sense of community', 'inner life', 'meaningful work', 'transcendence', 'compassion', and 'mindfulness'.

This study focuses on WPS conceptualized by Petchsawang and Duchon (2009) which has the following four dimensions.

Compassion: In a broad sense, compassion means empathy or care for the suffering of others, often including a desire to help. Petschsawang and Duchon (2009) defined this dimension of WPS as "a deep awareness of and sympathy for others and a wish to relieve their suffering that leads to responsibility for another who is less fortunate or suffering" (p. 461).

Mindfulness: Mindfulness, in Buddhist spiritual tradition, is largely attributed to a person's moment-by-moment awareness of his/her thoughts, feelings, bodily sensations, and surrounding environment (http://greatergood.berkeley.edu/topic/mindfulness/definition). This dimension of WPS is defined as "a state of inner consciousness in which one is aware of one's thoughts and actions moment by moment. It is about a person's mind being present, not wandering with past, future thoughts or distractions." (Petschsawang \& Duchon, 2002, p. 461).

Meaningful work: Meaningful work basically reflects the extent to which employees experience a sense of meaning and purpose at their work. Petchsawang and Duchon (2009) defined meaningful work as "one's experience that his/her work is a significant and meaningful part to his/her life, the meaning is beyond the material rewards and creates a sense of joy and energy at work" (p. 463).

Transcendence: An important dimension of WPS is whether employees can interpret their work practices and their organizations' operations in sacred terms (Wuthnow, 1995, as cited in Grant, O'Neil, and Stephens, 2004). Worthington Jr et al. (2010) define spirituality as "a person's experience of relationship with the sacred" (p. 120), where the sacred could be a God as well as other objects such as nature, cosmos, or humanity. Petchsawang and Duchon (2009) defined the connection to higher power as transcendence dimension of WPS. But these authors explicitly make it clear that it does not involve a feeling of being connected with God.

\section{Job Satisfaction and Workplace Spirituality}

It has been well established in organizational literature that job satisfaction of employees is a preeminent job attitude, which is crucial for the success of any organization. Job satisfaction is a 
pleasurable or positive emotional state that arises from the appraisal of one's job or job experience (Locke, 1976). Spector (1997) described job satisfaction as simply how people feel about their jobs and different aspects of their jobs. On the other hand, Lawler (1990) defines job satisfaction as people's feelings about the rewards they have received on the job (as cited in Chen \& Silverthrone, 2008). Job satisfaction has been linked with several employee outcomes such as organizational commitment (e.g., Shrestha, 2012), task performance, organizational citizenship behavior, and counterproductive work behavior (e.g., Dalal, Baysinger, Brummel, \& LeBreton, 2012). There is also past evidence that job satisfaction lowers employees' intent to turnover, absenteeism, and negligent behavior (e.g., Shrestha, 2012). Therefore, it is important to research the antecedent of job satisfaction.

Several theories have been proposed to explain job satisfaction. The theoretical conceptualizations on determinants of job satisfaction can be divided into three categories - situational approaches, dispositional approaches and interactionist approaches (Cohrs, Abele, \& Dette, 2006). Among these approaches, dispositional model and need fulfillment theory have been widely used while identifying determinants of job satisfaction (St Van der Walt \& de Klerk, 2014). Studies examining job satisfaction from dispositional perspective have identified personality variables, core self-evaluations, organizational status and seniority, and general life satisfaction as determinants of job satisfaction (e.g., Cohrs et al, 2006; Judge, Locke, Durham, \& Kluger, 1998). On the other hand, need fulfillment theory posits that employees' satisfaction with their job depends upon the extent to which one's needs are fulfilled from their job. The needs may vary from materialistic needs such as monetary rewards/incentives or promotion opportunities to spiritual needs such as purpose and meaning in work, alignment of personal values, thoughts, and actions with the job, involvement in the work that relieve the sufferings of the others, and work as a means to connect with the higher self.

When looked at from the need fulfillment perspective, the changing nature of contemporary employees may demand the organizations not to rely on fulfilling materialistic needs of the employees so as to keep them satisfied in their job but will force the organizations to view job satisfaction from a new perspective that focuses on spiritual values and belief systems of the employees (St Van der Walt $\&$ de Klerk, 2014). However, there is limited empirical evidence linking WPS to job satisfaction since only a few studies (e.g., Chawala \& Guda, 2010; Kolodinsky, Bowen, \& Ferris, 2003; Milliman et al., 2003; St Van der Walt \&de Klerk, 2014) have reported positive influence of some dimensions of WPS on job satisfaction, and only one study (Gupta, Kumar \& Singh, 2014) has investigated the relationship between single composite score of WPS and job satisfaction. Kinjerski and Skrypnek (2004) argue that though WPS is broken down to different dimensions to explore different aspects of it and to understand it fully, it is a holistic experience. Similarly, Indratono and Wulandari (2013) argue that since WPS can be meaningfully conceptualized at higher orders of abstraction as well as single composite score level, a higher order modeling approach would be most appropriate. This study proposes that:

H1: Higher level of WPS will lead to higher level of job satisfaction.

\section{Job Involvement and Workplace Spirituality}

Several conceptualizations of job involvement are found in literature. However, the concept of job involvement was first introduced in organization literature by Lodahl and Keigner (1965). According to these authors, job involvement is defined as " the degree to which a person identifies with his or her job, actively participates in it, and considers his or her performance important to a sense of self-worth, self-esteem, or self-image" (Word, 2012, p.155). Later, Kanungo (1982) defined it as "a belief 
descriptive of the present job and tends to be a function of how much the job can satisfy one's present need" (p. 342).

Brown (1996), in his meta-analytic examination of the antecedents of job involvement, suggested that there are three different perspectives - individual difference perspective, situationist perspective, and interactionist perspective - while studying antecedents of job involvement. The individual difference perspective considers personality variables as major antecedents of job involvement, whereas situationist perspective posits that the change in job involvement is dependent upon job context. On the other hand, the interactionist perspective posits that personality and situational factors jointly influence job involvement (as cited in Brown 1996). The results of meta-analysis revealed that personality variables as well as situational variables are significantly related to job involvement. Carmeli (2005) also posits that there are two distinct arguments found in literature regarding how different factors influence job involvement. One argument is that situational factors influence employees' involvement in their jobs. The other argument views job involvement as personal characteristic. Earlier, it was believed that both the factors are equally important while predicting the job involvement of individuals, but later studies have suggested that perceived situational characteristics accounted for larger portion of variance than personal characteristics (Word, 2012).

Past studies examining the influence of job involvement with employee attitudes and behaviors have shown that job involvement is a determinant of employee absence, withdrawal intentions, turnover intentions, job performance, individual motivation and organizational commitment (e.g., Shrestha, 2012; Uygur and Kilic, 2009). Owing to its positive influence on several employee outcome variables, it is important to identify the determinant of job involvement. Job involvement is a widely researched construct and there is no dearth of literature suggesting determinants of it. However, in the present context, as Schreuder and Coetzee (2006, as cited in Van der Walt \& de Klerk, 2014) suggest, work is viewed as a means to discover purpose in life as well as a mode of self-expression. Individuals are likely to prefer or get involved in the job if the work is worthy of human spirit and expresses their spirit (Garcia-Zamor, 2003) as it has become difficult for employees to segregate their work and nonwork lives by stopping their spiritual selves entering their work domain. Therefore, it is plausible to consider WPS as an important determinant of job involvement.

A review of literature on empirical studies related to WPS by Geigle (2012) listed only two studies that investigated the relationship between organizational spirituality and job involvement. Kolodinsky, Bowen, and Ferris (2008) found a positive relationship between organizational spirituality and satisfaction, involvement, commitment, and organizational citizenship behavior (OCB). Milliman et al.'s (2003) study found a significant positive relationships between sense of community and meaningful work dimensions of WPS and job involvement. However, no studies have tested the relationship between WPS as conceptualized by Petchsawang and Duchon (2009) and job involvement. Therefore, it is hypothesized that:

H2: Higher level of WPS will lead to higher level of job involvement.

Perceptions of Organizational Politics, Workplace Spirituality, and Employee Attitudes

Organizational politics in general refers to the organizational members' subjective experiences and perceptive evaluation of the individual, group or organizational activities to pursue individual benefits (Ferris \& Kacmar, 1992). There are two different perspectives found in the organization literature pertaining to organizational politics (Gotsis \& Kortezi, 2009). First perspective characterizes it as a manifestation of social influence process for gaining beneficial organizational outcomes. For example, 
employees may be engaged in some political activities that are sanctioned by the organization and are beneficial to work group or organization. On the other hand, the second perspective views it as selfserving and unsanctioned attempts perceived by the organizational actors such as favoritism-based pay and promotion decisions, and backstabbing. By combining these two different perspectives, Cropanzano, Howes, Grandey, and Toth (1995) defined it as social influence attempts directed at those who can provide rewards that will help promote or protect the self-interests of the actor.

In the past decades, especially after the proposition of POP model by Ferris, Fuss, and Fandt (1989) and development of perceptions of politics scale (POPS) by Kacmar and Ferris (1991), numerous studies have examined the relationship between POP and employee outcomes. These studies demonstrate that POP have detrimental effect on employee outcomes such as job satisfaction, organizational commitment, organizational citizenship behavior, turnover intentions. For example, Meisler and Vigoda-Gadot (2014), while examining the direct and indirect effects of emotional intelligence on employee outcomes, found that POP negatively influences job satisfaction, and positively influences turnover intentions and negligent behavior. Similarly, Abbas, Raja and Darr's (2014) study indicated negative relationship between POP and job satisfaction. Chang, Rosen and Levy's (2009) meta-analysis also found significant negative influence of POP on outcomes. On the other hand, few studies (e.g., Shrestha, 2012) have examined the effect of POP on job involvement, which indicate that POP negatively affects job involvement.

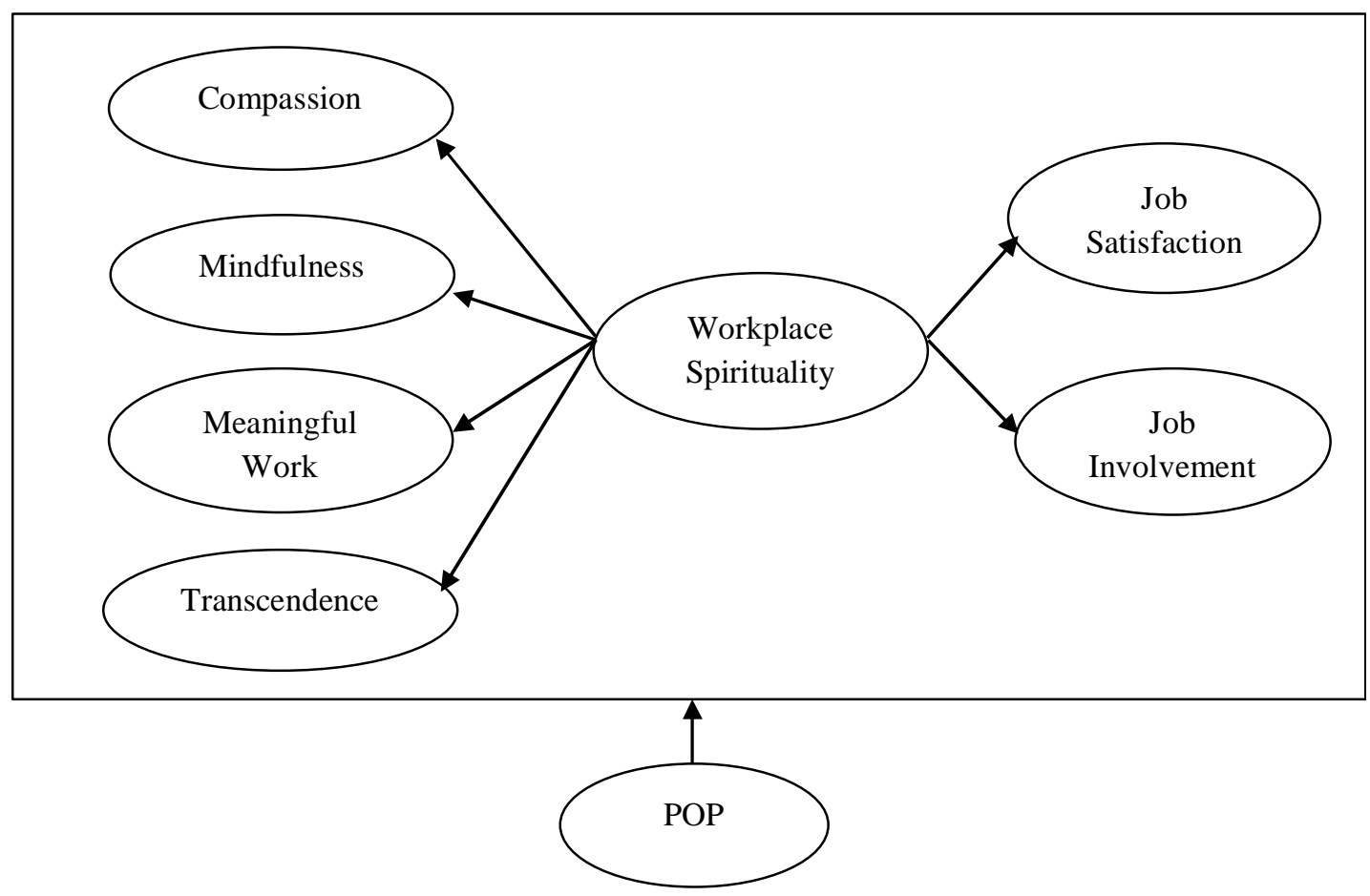

Figure 1. The Research Model

Although there is growing number of research examining the influence of WPS on employee outcomes, few studies that investigated the relationships between WPS with employee attitudes appear 
to be consistent. Scholars (e.g., Word, 2012) point to the fact that examination of impact of individual and organizational factors on the influence of WPS on employee attitudes such as job involvement have not been addressed yet. As POP has been empirically found to have significant negative influence on employee outcomes and this study proposes positive relationships between WPS and job involvement, it is proposed that:

H3: Perceptions of organizational politics will moderate the positive relationships between WPS and (a) job satisfaction and (b) job involvement, such that the relationships will be weaker when POP is high.

\section{Method}

\section{Population and Sample}

Population of this study included employees working in two Nepali organizations (a security agency and a telecom service provider with nation-wide network). Four hundred questionnaires were distributed to each organization. Five hundred thirteen completed questionnaires were returned (a response rate of 64.12 percent), out of which 480 were found usable. The questionnaire comprised of items of study variables as well as six socio-demographic variables - age, sex, marital status, educational qualification, position in the organization, number of years employed in the present organization and employees' organization. The number of respondents from each organization was nearly equal $($ Telecom $=52 \%$, Security agency, 48\%). Eighty eight percent of the respondents were males, and the average age was 36.24 years $(\mathrm{SD}=8.69)$. Majority of the respondents were officers $(69 \%)$, and their average experience was13.11 years $(\mathrm{SD}=8.15)$. Only about 21 percent of the respondents have educational qualification up to High School level. Rest of the respondents were graduates or post-graduates. Majority of the respondents (82.4 percent) were married.

\section{Measures}

For measuring WPS, a scale developed by Petchsawang and Duchon (2009) was used. This scale is a multi-dimensional scale, with four dimensions (compassion, mindfulness, meaningful work, and transcendence) and 22 items.

POP was assessed using two dimensions (General Political Behavior and Go along To Get Ahead) of perceptions of organizational politics scale (POPS) developed by Kacmar and Carlson (1997). These two dimensions have nine items.

To assess job involvement, Kanungo's (1982) 10-item scale was used. Three items of Michigan Organizational Assessment Questionnaire (MOAQ) Job Satisfaction Subscale (Cammann, Fichman, Henkins \& Klesh, 1979) measured the level of job satisfaction. 5-point Likert scales used with anchors strongly disagree (1) to strongly agree (5). The scales were summed to create an overall score for each variable, with higher scores indicating the higher levels of respective constructs.

\section{Preliminary Analysis}

Shapiro-Wilk test was conducted to test the normality of the data. Test results revealed that WPS and job involvement data were normally distributed $(p>.05)$, and tests were significant $(p<.01)$ in the case of job satisfaction and POP. However, the values of skewness and kurtosis ranged between -.46 to .28 , allowing for the analysis to proceed. 
Reliability analysis was conducted to assess the internal consistency reliability of the four measures used in this study. WPS and job involvement measures had Cronbach's alpha values above .70. The 3item MOAQ job satisfaction measure had alpha value .64 whereas the 10 -item job involvement measure had alpha value .78. The 9-item POP measure had alpha value .56 only. However, upon deletion of two reverse scored items of this measure, the alpha value increased to .68. Therefore, the two items were removed while calculating the aggregate score of POP.

Since, WPS and POP are multi-dimensional scales, confirmatory factor analyses (CFA) were carried out using LISREL 8.8 for Windows to assess whether the items of the scale load onto intended factor. In case of WPS, the CFA result revealed that one item of compassion dimension did not load to the intended dimension (factor loading < .30). This item was dropped from the scale. Dropping of one item increased the value of Cronbach's alpha from .82 to .84. The measurement model with 21 items consisting of four first order factors showed a good fit: $\chi^{2}[183]=349.70, p=.00$, RSMEA $=.04$, CFI $=.97, \mathrm{IFI}=.97$. The second-order model comprising of four first-order factors and one second-order factor of WPS also showed good fit with the data $\left(\chi^{2}[188]=367.13, p=.22\right.$, RSMEA $=.02$, CFI $=$ .97 , IFI $=.97)$. Similarly, the two first order factors of 7-item POP scale also showed a good fit to the data: $\chi^{2}[13]=15.34, p=.00$, RSMEA $=.04, \mathrm{CFI}=1.00$, IFI $=1.00$. The model with two first order factors and one second-order factor of POP also showed good fit with the data $\left(\chi^{2}[12]=15.49, p=\right.$ .29 , RSMEA $=.02, \mathrm{CFI}=.99$, IFI $=.99)$. Two items of 10 -item job involvement scale had factor loadings below acceptable level $(<.30)$. Dropping of these two items improved the model fit: $\chi^{2}[20]=$ $86.61, p=.00, \mathrm{RSMEA}=.08, \mathrm{CFI}=.97, \mathrm{IFI}=.97$. The value of Cronbach's alpha also increased from .78 to .84 .

\section{Assessment of Convergent and Discriminant Validity}

The standardized loadings of the items and squired multiple correlations $\left(R^{2}\right)$ are presented in Table 1 . The model has a good fit to data: $\left(\chi^{2}[674]=1232.89, p=.00, \operatorname{RSMEA}=.043, \mathrm{CFI}=.96\right.$, IFI $\left.=.96\right)$. Except two items of transcendence dimension of WPS and one item of GTGA dimension of POP, all the items have factor loadings above .50 and are statistically significant (at least at $p<.05$ ). Thus, the constructs in general have good convergent validity.

Table 1:

Indicators of Convergent Validity

\begin{tabular}{lcc}
\hline Items & Estimate & $R^{2}$ \\
\hline Compassion & & \\
COM 1 & .56 & .31 \\
COM 2 & .68 & .47 \\
COM 3 & .60 & .36 \\
Meaningful work & & \\
MFW 1 & .65 & .34 \\
MFW 2 & .59 & .39 \\
MFW 3 & .64 & .49 \\
MFW 4 & .71 & .51 \\
MFW 5 & .57 & .47 \\
MFW 6 & .63 & .46 \\
\hline
\end{tabular}




\section{Table 1 Contd.}

\section{Transcendence}

TRN 1

.42

.18

TRN 2

.62

.38

TRN 3

.68

.46

TRN 4

.40

.16

TRN 5

.65

.43

Mindfulness

MFN 1

MFN 2

.62

.39

MFN 3

.70

.49

MFN 4

.72

.51

MFN 5

.70

.47

MFN 6

.68

.46

General Political Behavior (GPB)

GPB 1

.66

.44

GPB 2

.66

.43

Go along To Get Ahead (GTGA)

GTGA 1

GTGA 2

GTGA 3

GTGA 4

.51

.26

GTGA 5

.53

.28

Job Involvement

JI 1

JI 2

JI 3

JI 4

JI 5

JI 6

JI 7

JI 8
.61

.63

.64

.65

.58

.55

.72

.62
.38

.40

.40

.43

.34

.30

.51

.39

Job Satisfaction

JS 1

JS 2

.68

JS 3 
A series of CFA was conducted to examine whether four constructs of this study captured distinct versus common source effects. As compared to three alternate models, the four factor model comprising of WPS, POP, job satisfaction, and job involvement as four separate constructs had a better fit to the data $\left(\chi^{2}[696]=3192.83, p=.00, \mathrm{RSMEA}=.087, \mathrm{CFI}=.88, \mathrm{IFI}=.88\right)$. A single factor model formed by combining all the items of four construct did not have a good fit to the data $\left(\chi^{2}=4457.4\right.$ [665], $p=.00$, RSMEA $=.11, \mathrm{CFI}=.82$, IFI $=.82$ ). A two-factor model consisting of WPS items as one factor and another factor formed by combining the items of POP, job satisfaction, and job involvement also did not show a good fit to data $\left(\chi^{2}[701]=3837.42, p=.00\right.$, RSMEA $=.097, \mathrm{CFI}=$ .85 , IFI $=.85$ ). Another model comprising of three factors - WPS, POP, and a third factor comprising of items of job satisfaction and job involvement also had a poor fit to data $\left(\chi^{2}[699]=3314.89, p=.00\right.$, RSMEA $=.089, \mathrm{CFI}=.87, \mathrm{IFI}=.87)$ as compared to the four-factor model. The CFA results provide support for the discriminant validity of four study variables.

\section{Results}

Table 2 provides descriptive statistics and intercorrelations of study variables. As expected, WPS is positively correlated with job satisfaction and job involvement. At individual dimension level, all four dimensions of WPS were positively correlated with job satisfaction. However, job involvement has significant positive relationships only with three dimensions (compassion, meaningful work, and transcendence) of WPS.

Table 2: Means, standard deviations, intercorrelations of study variables

\begin{tabular}{llrrrrrrrrr}
\hline & Mean & SD & 1 & 2 & 3 & 4 & 5 & 6 & 7 \\
\hline 1 & WPS & 3.76 & 0.48 & & & & & & & \\
2 & Compassion & 3.92 & 0.67 & $.62^{* *}$ & & & & & & \\
3 & Mindfulness & 3.79 & 0.83 & $.57 * *$ & $.12^{*}$ & & & & & \\
4 & Meaningful Work & 3.81 & 0.65 & $.81^{* *}$ & $.52^{* *}$ & $.13^{* *}$ & & & & \\
5 & Transcendence & 3.57 & 0.65 & $.69^{* *}$ & $.43^{* *}$ & .02 & $.60^{* *}$ & & & \\
6 & Job Satisfaction & 3.64 & 0.80 & $.36^{* *}$ & $.24^{* *}$ & $.16^{* *}$ & $.37 * *$ & $.23^{* *}$ & & \\
7 & Job Involvement & 3.34 & 0.72 & $.39^{* *}$ & $.28^{* *}$ & -.07 & $.51^{* *}$ & $.42^{* *}$ & $.47^{* *}$ & \\
8 & POP & 3.39 & 0.60 & .06 & $.13^{* *}$ & $-.11^{*}$ & .06 & $.20^{* *}$ & $-.16^{* *}$ & .09 \\
\hline
\end{tabular}

Note: $* p<.05 ; * * p<.01$

Since the sample was drawn from two organizations with markedly different purpose, independent sample t-tests were carried out to assess whether there is significant different between the samples from two organizations on their - (i) experience of spirituality at workplace; (ii) perceptions of prevalence of politics in the organization; (iii) involvement in the job and (iv) satisfaction with their job. Significant difference was found only in the case of job involvement. Employees form the security agency were found to have more involvement in their job as compared to employees from telecom service provider. 
The results of structural analysis are shown in Figure 2. The fit indices of the structural model showed an acceptable fit to data $\left(\chi^{2}[458]=994.57, p=.00, \mathrm{RSMEA}=.049, \mathrm{CFI}=.96, \mathrm{IFI}=.96\right)$. All path coefficients except for mindfulness dimension of WPS are significant $(\mathrm{p}<.01)$. WPS was significantly positively related to job satisfaction $(\beta=.59, p<.01)$ and job involvement $(\beta=.64, p<$ $.01)$. Thus, hypotheses 1 and 2 were supported.

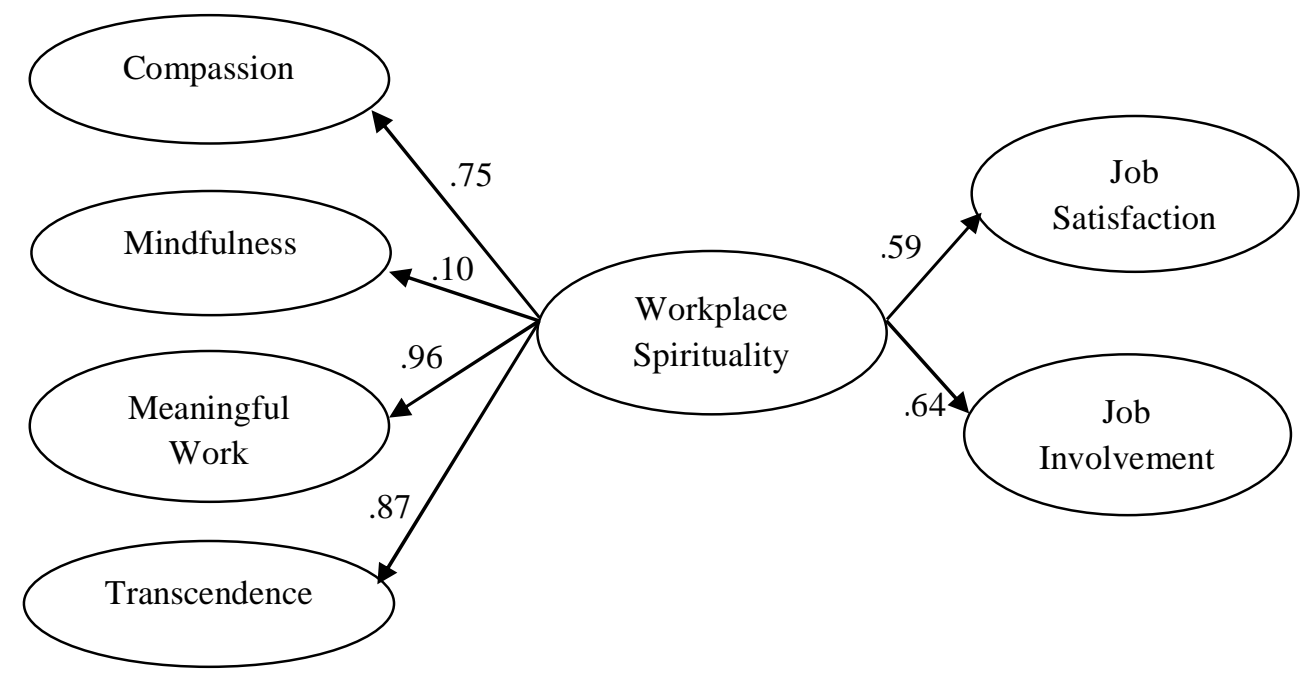

Figure 2. Structural Model with Standardized Path Coefficients

Table 3

$M M R$ results for the moderating effect of POP on WPS- job attitudes relationships

Dependent Variables

\begin{tabular}{lcc}
\hline Independent Variables & Job Satisfaction & Job Involvement \\
\hline Model 1 & & \\
WPS & $0.37^{* *}$ & $0.41^{* *}$ \\
POP & $-0.18^{* *}$ & 0.01 \\
$R^{2}$ & 15.9 & 16.8 \\
$F$ & $36.4^{* *}$ & $36.99 * *$ \\
Model 2 & & \\
WPS & -0.03 & -0.31 \\
POP & -0.75 & $-1.04^{*}$ \\
WPS $\times$ POP & $0.71^{\Phi}$ & $1.33^{* *}$ \\
$R^{2}$ & 16.5 & 19.5 \\
$F$ & $25.27^{* *}$ & $29.31^{* *}$ \\
\hline
\end{tabular}

Note: ${ }^{\phi} p<.1 ; * p<.05 ; * * p<.01$

Journal of Business and Management Research, July 2017, Vol. 2, No. 1 \& 2 
Moderated multiple regression (MMR) analysis was used to examine the moderating effect of POP on the relationships between WPS and employee attitudes. In the first step of the regression, effects of WPS and POP on dependent variable was investigated. In the second step, WPS, POP and the interaction of WPS with POP were regressed on the dependent variables. The results of MMR analyses are presented in Table 3. The regression results reveal that WPS has significant positive relationships with job satisfaction and job involvement as the coefficients of main effects are significant $(p<.01)$ for both the dependent variables.

In the second models, the interaction term $($ WPS $\times$ POP) is significant $(p<.01)$ in the case of job involvement and is marginally significant $(\mathrm{p}<.10)$ in the case of job satisfaction. These results indicate partial support for Hypotheses 3.

Moderating effect of POP on the relationship between WPS and job involvement is graphically presented in Figure 3.

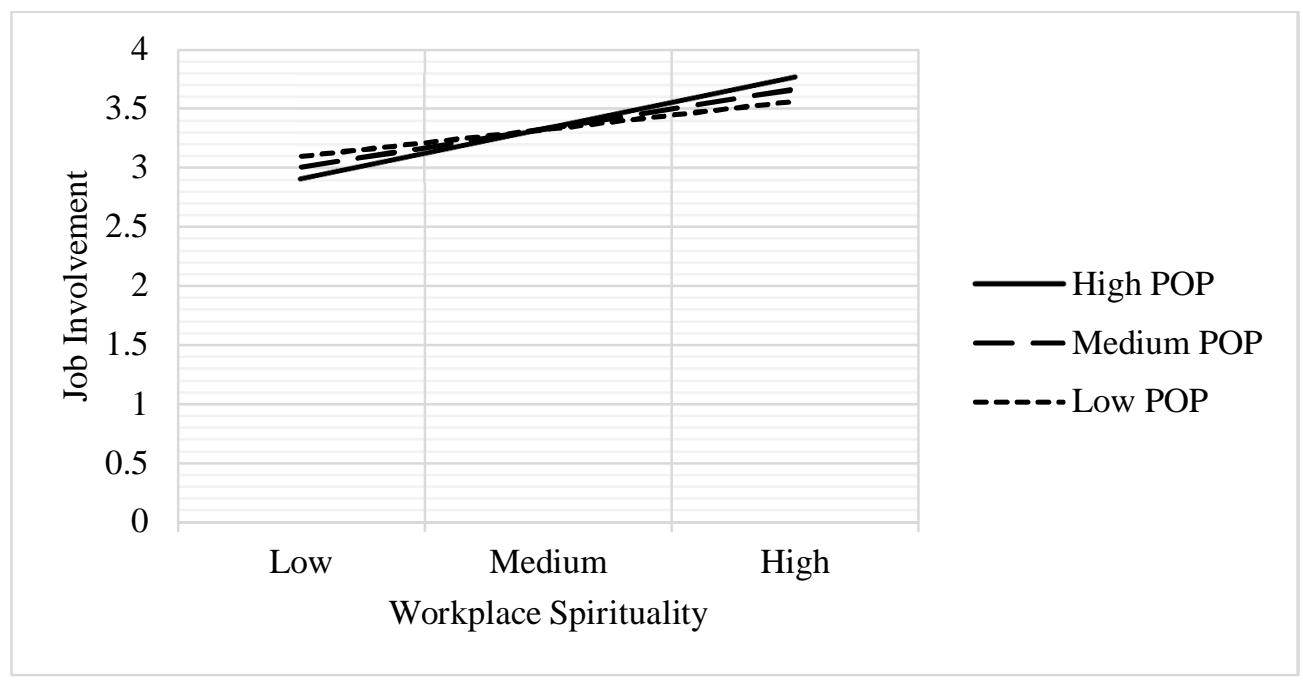

Figure 3. Moderating effect of POP on workplace spirituality - job involvement relationship

\section{Discussion}

The purpose of this study was to examine how WPS is linked to two important employee attitudes job satisfaction and job involvement, and how these linkages differ according to employees' perceptions of prevalence of politics in their organizations. Consistent with the study's prediction, WPS was found to have positive influence on job satisfaction and job involvement. However, when POP was tested as a moderator in the relationship between WPS and two employee attitude variables, significant and marginally significant interaction effects provided partial support for the third hypothesis, which suggests that employees' perceptions of organizational politics shaped the relationships between WPS and employee attitudes. 
This study confirmed the findings of previous studies (e.g., Chawla \& Guda, 2010; Kinjerski \& Skrypnek, 2008; Usman \& Danush, 2010; Van der Walt \& de Klerk, 2014) that WPS positively influences job satisfaction. However, it should be noted that these studies used WPS scales that have different dimensions (mainly sense of community at work, alignment with organization's values, and meaningful work). Despite the use of different scale having different dimensions for capturing WPS, the consistency of present finding with findings of previous studies and moderate correlation $(\gamma=.36, p$ $<.01)$ indicate that WPS is an important antecedent of job satisfaction. It should also be noted that all four dimensions are significantly positively correlated with job satisfaction. Thus, the current study supports the need fulfilment theory as a framework for understanding the influence of WPS on job satisfaction.

Few studies demonstrate the influence of WPS on job involvement as the review of literature by Geigle (2012) found only two studies that investigated the relationship between WPS spirituality and job involvement. These studies found positive influence of WPS on job involvement. In the present study, the strength of the correlation between spirituality and job involvement was moderate $(\gamma=.36, p$ $<.01$ ), which suggests that WPS is an important situational predictor of job involvement. However, it should be noted that at the individual dimension level, the relationship between mindfulness and job involvement was not significant. In the previous study also, all dimensions of WPS were not correlated with job involvement (e.g., Milliman et al., 2003).

This study is perhaps the first study examining the moderating effect of POP on WPS and job attitude relationships. The correlational analyses showed that POP is negatively related to job satisfaction, which is consistent with the findings of previous studies (e.g., Chang et al., 2009). Similarly, WPS had positive relationship with job satisfaction. But the MMR result could not confirm the moderating effect of POP on WPS - job satisfaction relationship since the interaction term was only marginally significant. Since previous studies have indicated that POP moderates the relationships between situational antecedents and job satisfaction, it is unlikely that POP does not moderate this relationship. Thus, it could be statistical artifact.

MMR results examining the moderating effect of POP on the relationship between WPS and job involvement showed that POP moderates this relationship. The graphical analysis (see Figure 3) shows that when WPS is low and if the employees perceive high level of prevalence of politics, their job involvement is low. On the other hand, if WPS is high, even with the high level of perceptions of prevalence of politics, the employees' job involvement will be high. This clearly indicates that WPS acts as antidote to POP.

\section{Implications}

\section{Theoretical Implications}

This study offers a number of important theoretical contributions. First, it enriches our understanding of the role of WPS in fostering positive employee attitudes. More specifically, the significant positive relationships between WPS and two attitudinal variables - job satisfaction and job involvement indicate that in addition to the situational antecedents identified by previous studies, WPS also plays an important role while predicting employee attitudes. Second, this study, which was conducted in an eastern context, confirms the findings of previous research studies investigating the relationship between WPS and job involvement in the western context. At the same time, it also demonstrates that the influence of WPS on employee attitudes is not limited to western workplace context. 
The findings also present important insight in the field of POP. The study demonstrated that POP had differential effects on employee attitudes as a significant negative relationship with job satisfaction and non-significant relationship with job involvement. However, it was found to have moderating effect on the relationship between WPS and job involvement. Closer examination of the moderating effect revealed that when WPS is low, with low level of perceptions of prevalence of politics, job involvement is high. But, when both the POP and WPS are high, job involvement is also high. This finding indicates that WPS can mitigate the dysfunctional effect of POP on WPS - job involvement relationship. To a certain extent, it also supports the arguments made by scholars (e.g., Ferris et al., 1989; Ferris \& Kacmar, 1992) that employees may react to high level of politics in their organization by getting themselves more involved in their jobs.

This study utilized Petchsawang and Duchon's (2009) scale for capturing WPS. Shrestha's (2016) validation study found support for validity and reliability of this scale. Present findings also provide additional validity support for this scale. Thus, future researchers will have more confidence in using this scale.

\section{Practical Implications}

Several practical implications for mangers can be drawn from the results of this study. Its findings help managers understand the importance of WPS in fostering positive employee attitudes. Managers who wish to increase their employees' job satisfaction and job involvement need to create an organizational environment in which employees can experience high WPS. Managers can do so by designing job in such a way that it provides a meaning in job to the employee as well as address employee need at a deeper level; by paying attention to continuous learning and development of employees, which will contribute to compassion at the workplace; by fostering a sense of transcendence through exercising leadership in such a way that it models behavioral integrity, promote psychological safety, and respect an employee's identity, value, and purpose and meaning in life (Petchsawang \& Duchon, 2009).

The findings can also be used by managers to identify the attitudinal problems in their organizations. Particularly, the results of this study indicated that employees' perceptions of prevalence of politics in their organization have direct and/or indirection influence on employee attitudes. Therefore, when managers encounter attitudinal problems among their employees, they need to find out whether these problems originate from employees' reaction to POP.

\section{Limitations and Future Research Directions}

Despite this study's contribution to WPS literature, it does have a number of limitations that need to be highlighted. First, this study used self-report scales for capturing study constructs. Relying solely on self-reported measures could lead to common method variance. In order to enhance confidence in present findings, future studies should collect data from different sources, e.g., from supervisors, peers, subordinates. Second, the study design was cross-sectional in nature, which introduces a restriction in establishing direction of causality. To overcome this restriction, future studies might include the longitudinal design for testing the hypothesized relationships of this study. Third, this study examined the relationship between WPS and job satisfaction. From a need fulfillment perspective, job satisfaction could be result from the fulfillment of both materialistic need and non-materialistic need, whereas WPS would have more pronounced influence on non-materialistic need. Researchers in future might test this relationship. In addition, as this study was limited to exploring the relationships between 
WPS and two job attitude variables, there is a need to examine the influence of WPS on other attitudinal factors, as well as behavioral outcomes (e.g., job stress, counter-productivity work behavior, cynicism, absenteeism, turnover intentions, and organizational citizenship behavior). Fourth, the current study examined the moderating effect of POP on WPS and the relationship of employee attitudes. As the study could not confirm the moderating effect of POP on WPS - job satisfaction relationship, further study is warranted so as to confirm whether POP moderates this relationship. Furthermore, moderating effects of other situational variables (such as perceived organizational support) and individual difference variables (such as personality characteristics) should also be explored. Finally, there are numerous studies that explore the antecedents of attitudes of employees. This study has confirmed the WPS is an important predictor of employee attitudes. Since it has been empirically established that attitudes shape behaviors and performance of employees, future study should empirically examine the relative importance of different antecedents in predicting employee attitudes.

In conclusion, this study has contributed to the extant knowledge on influence of WPS on employee attitudes. This study is perhaps the first study that examined the moderating role of POP on WPS and employee attitude relationships and provides initial evidence of moderating effect of POP on WPS attitude relationship, setting ground for further research.

\section{References}

Abbas, M., Raja, U., Darr, W., \& Bouckenooghe, D. (2014). Combined effects of perceived politics and psychological capital on job satisfaction, turnover intentions, and performance. Journal of Management, 40(7), 1813-1830. http://dx.doi.org/10.1177/0149206312455243

Ashar, H., \& Lane-Maher, M. (2004). Success and spirituality in the new business paradigm. Journal of Management Inquiry, 13(3), 249-260. http://dx.doi.org/10.1177/1056492604268218

Byrne, C. J., Morton, D. M., \& Dahling, J. J. (2011). Spirituality, religion, and emotional labor in the workplace. Journal of Management, Spirituality \& Religion, 8(4), 299-315. http://dx.doi.org/10.1080/14766086.2011.630169

Carmeli, A. (2005). Exploring determinants of job involvement: an empirical test among senior executives. International Journal of Manpower, 26(5), 457-472.

Chag, C., Rosen, C. C., \& Levy, P. E. (2009). The relationship between perceptions of organizational politics and employee attitudes, strain, and behavior: A meta-analytic examination. Academy of Management Journal, 22(4), 779-801.

Chawla, V., \& Guda, S. (2010). Individual spirituality at work and its relationship with job satisfaction, propensity to leave and job commitment: An exploratory study among sales professionals. Journal of Human Values, 16(2), 157-167. http://dx.doi.org/10.1177/097168581001600203

Chen, J., \& Silverthrone, C. (2008). The impact of locus of control on job stress, job performance and job satisfaction in Taiwan. Leadership and Organization Development Journal, 29(7), 572-582. http://dx.doi.org/10.1108/01437730810906326

Cohrs, J. C., Abele, A. E., \& Dette, D. E. (2006). Integrating situational and dispositional determinants of job satisfaction: Findings from three samples of professionals. The Journal of Psychology, $140(4), 363-395$.

Cropanzano, R., Howes, J.C., Grandey, A., \& Toth, P. (1997). The relationship of organizational politics and support to work behaviors, attitudes, and stress. Journal of Organizational Behavior, 
18(2), 159-180. $\quad$ http://dx.doi.org/10.1002/(SICI)1099-1379(199703)18:2<159::AIDJOB795>3.0.CO;2-D

Daniel, J. L. (2015). Workplace spirituality and stress: Evidence from Mexico and US. Management Research Review, 38(1), 29-43.

Dhiman, S., \& Marques, J. (2011). The role and need of offering workshops and courses on workplace spirituality. Journal of Management Development, 30(9), 816-835. http://dx.doi.org/10.1108/MRR07-2013-0169

Dirkx, J. M. (2013). Leaning in and leaning back at the same time: Toward a spirituality of work related learning. Advances in Developing Human Resources, 15(4), 356-369. http://dx.doi.org/10.1177/1523422313498562

Duchon, D., \& Plowman, D. A. (2005). Nurturing the spirit at work: Impact on work unit performance. The leadership quarterly, 16(5), http://dx.doi.org/10.1016/j.leaqua.2005.07.008

Fagley, N., \& Adler, M. (2012). Appreciation: A spiritual path to finding value and meaning in the workplace. Journal of Management, Spirituality \& Religion, 9(2), 167-186. http://dx.doi.org/10.1080/14766086.2012.688621

Faro Albuquerque, I., Campos Cunha, R., Dias Martins, L., \& Brito Sá, A. (2014). Primary health care services: workplace spirituality and organizational performance. Journal of Organizational Change Management, 27(1), 59-82. http://dx.doi.org/10.1108/JOCM_11_2012-0186

Ferris, G. R., \& Kacmar, K. M. (1992). Perceptions of organizational politics. Journal of Management, 18(1), 93-116.

Ferris, G. R., Russ, G. S., \& Fandt, P. M. (1989). Politics in organizations. In R. A. Giacalone and P. Rosenfield (Ed.). Impression management in the organization, pp. 143-170. Hillside, NJ: Erlbaum.

Garcia-Zamor, J. C. (2003). Workplace spirituality and organizational performance. Public Administration Review, 63(3), 355-363. http://dx.doi.org/10.1111/1540-6210.00295

Geigle, D. (2014). Workplace spirituality empirical research: A literature review. Business and Management Review, 2(10), 24-27.

Giacalone, R. A., \& Jurkiewicz, C. L. (2003). Toward a science of workplace spirituality. In R. A. Giacalone \& C. L. Jurkiewicz (Eds.), Handbook of workplace spirituality and organizational performance (pp. 3-28). New York: M. E. Sharpe.

Gotsis, G., \& Kortezi, Z. (2009). Ethical considerations in organizational politics: Expanding the perspective. Journal of Business Ethics, 94(3), 497-515. http://dx.doi.org/10.1007/s10551-0090241-7

Grant, D., O’Neil, K., \& Stephens, L. (2004). Spirituality in the workplace: New empirical directions in the study of the sacred. Sociology of Religion, 63(5), 265-283. https://doi.org/10.2307/3712252

Gupta, M., Kumar, V., \& Singh, M. (2014). Creating satisfied employees through workplace spirituality: A study of the private insurance sector in Punjab (India). Journal of Business Ethics, 122(1), 79-88. http://dx.doi.org/10.1007/s10551-013-1756-5

Hong, Y. J. (2012). Identifying spirituality in workers: A strategy for retention of community mental health professionals. Journal of Social Service Research, 38(2), 175-186.

http://dx.doi.org/10.1080/01488376.2011.615275

Howard, S. (2002). A spiritual perspective on learning in the workplace. Journal of Managerial Psychology, 17(3), 230-242. http://dx.doi.org/10.1108/02683940210423132

Indartono, S., \& Wulandari, S. Z. (2014). Moderation effect of gender on workplace spirituality and commitment relationship: case of Indonesian ethics. Asian Journal of Business Ethics, 3(1), 65-81. http://dx.doi.org/10.1007/s13520-013-0032-1 
Judge, T. A., Locke, S., Durham, C. C., \& Kluger, A. N. (1998). Dispositional effects on job and life satisfaction: The role of core evaluations. Journal of Applied Psychology, 83(1), 17-34.

Kacmar, K. M., \& Carlson, D. S. (1997). Further validation of the perceptions of politics scale (POPS): A multiple sample investigation. Journal of management, 23(5), 627-658. https://dx.doi.org/10.1016/S0149-2063(97)90019-2

Kacmar, K.M., \& Ferris, G.R. (1991). Perceptions of organizational politics scale (POPS): Development and construct validation. Educational and Psychological Measurement, 51(1), 193205. http://dx.doi.org/10.1177/0013164491511019

Kanungo, R. N. (1982). Measurement of job and work involvement. Journal of Applied Psychology, 67(3), 341-349. http://dx.doi.org/10.1037/0021-9010.67.3.341

Kolodinsky, R. W., Bowen, M. G., \& Ferris, G. R. (2003). Embracing workplace spirituality and managing organizational politics: Servant leadership and political skill for volatile times. In R. A. Giacalone \& C. L. Jukiewicz (Eds.), Handbook of Workplace Spirituality and Organizational Performance (pp. 164-180). New York, NY: M. E. Sharpe, Inc.

Kinjerski, V. M., \& Skrypnek, B. J. (2004). Defining spirit at work: Finding common ground. Journal of Organizational Change Management, $\quad 17(1), \quad 26-42$. http://dx.doi.org/10.1108/09534810410511288

Kinjerski, V. M., \& Skrypnek, B. J. (2008). The promise of spirit at work: Increasing job satisfaction and organizational commitment and reducing turnover and absenteeism in long-term care. Defining spirit at work: Finding common ground. Journal of Jerontological Nursing, 34(10), 17-25. http://dx.doi.org/10.3928/00989134-20081001-03

Lee, S., Lovelace, K. J., \& Manz, C. C. (2014). Serving with spirit: An integrative model of workplace spirituality within service organizations. Journal of Management, Spirituality \& Religion, 11(1), 45-64. http://dx.doi.org/10.1080/14766086.2013.801023

Meisler, G., \& Vigoda-Gadot, E. (2014). Perceived organizational politics, emotional intelligence and work outcomes: empirical exploration of direct and indirect effects. Personnel Review, 43(1), 116135. http://dx.doi.org/10.1108/PR-02-2012-0040

Marques, J. (2010). Workplace spirituality versus workplace politics: What's wrong with becoming a "NON"? Human Resource Management International Digest, 18(4), 3-6. http://dx.doi.org/10.1108/09670731011051441

Miller, B. K., Rutherford, M. A., \& Kolodinsky, R. W. (2008). Perceptions of organizational politics: A meta-analysis of outcomes. Journal of Business Psychlogy, 22(3), 209-222. http://dx.doi.org/10.1007/s10869-008-9061-5

Milliman, J., Czaplewski, A. J., \& Ferguson, J. (2003). Workplace spirituality and employee work attitudes: An exploratory empirical assessment. Journal of Organizational Change Management, 16(4), 426-447. http://dx.doi.org/10.1108/09534810310484172

Mitroff, I. I., \& Denton, E. A. (1999). A study of spirituality in the workplace. Sloan Management Review 40(4), 83-93.

Pawar, B. S. (2008). Two approaches to workplace spirituality facilitation: a comparison and implications. Leadership \& Organization Development Journal, 29(6), 544-567. http://dx.doi.org/10.1108/01437730810894195

Petchsawang, P. \& Duchon, D. (2009). Measuring workplace spirituality in an Asian context. Human $\begin{array}{llll}\text { Resource Development } & \text { International, } & \text { 12(4), }\end{array}$ http://dx.doi.org/10.1080/13678860903135912 
Rosen, C. C., Harris, K. J., \& Kacmar, K. M. (2009). The emotional implications of organizational politics: A process model. Human Relations, 62(1), 27-57. http://dx.doi.org/10.1177/0018726708099836

Saks, A. M. (2011). Workplace spirituality and employee engagement. Journal of Management, Spirituality \& Religion, 8(4), 317-340. http://dx.doi.org/10.1080/14766086.2011.630170

Sheng, C. \& Chen, M. (2012). Workplace spirituality scale design: The view of oriental culture. Business and Management Research, 1(4), 46-62. https://doi.org/10.5430/bmr.v1n4p46

Shrestha, A. K. (2016). Further Validation of Workplace Spirituality Scale in an Eastern Context. Journal of Business and Management Research, 1(1), 1-13. http://dx.doi.org/10.3126/jbmr.v1i1.14547

Shrestha, A. K., \& Baniya, R. (2016). Emotional intelligence and employee outcomes: Moderating role of organizational politics. Business Perspectives and Research, 4(1), 15-26. http://dx.doi.org/10.1177/2278533715605426

Shrestha, A. K., \& Mishra, A. K. (2015). Interactive effects of public service motivation and organizational politics on Nepali civil service employees' organizational commitment. Business Perspectives and Research, 3(1), 21-35. http://dx.doi.org/10.1177/2278533714551862

Srirangarajan, G. S., \& Bhaskar, R. K. (2011). Key dimensions of spirit at work - An Indian perspective. Journal of Human http://dx.doi.org/10.1177/097168581101700201

Standifer, R. L., Evans, K. R., \& Dong, B. (2010). The influence of spirituality on buyer perception within business-to-business marketing relationships: A cross-cultural exploration and comparison. Journal of Relationship $\quad$ Marketing, $\quad 9(3), \quad$ 132-160. http://dx.doi.org/10.1080/15332667.2010.505458

Thaker, K. B. (2009). Approaches to implement spirituality in business. Journal of Human Values, 15(2), 185-198. http://dx.doi.org/10.1177/097168581001500208

Uygur, A., \& Kilic, G. (2009). A study into organizational commitment and job involvement: An application towards the personnel in the central organization for Ministry of Health in Turkey. Ozean Journal of Applied Sciences, 2(1), 113-125.

Van der Walt, F., \& de Klerk, J. J. (2014). Workplace spirituality and job satisfaction. International Review of Psychiatry, 26(3), 379-389. http://dx.doi.org/10.3109/09540261.2014.908826

What is mindfulness? (n. d.). Retrieved from http://greatergood.berkeley.edu/topic/ /definition

Word, J. (2012). Engaging work as a calling: Examining the link between spirituality and job involvement. Journal of Management, Spirituality \& Religion, 9(2), 147-166. http://dx.doi.org/10.1080/14766086.2012.688622

Worthington Jr, E. L., Greer, C. L., Hook, J. N., Davis, D. E., Gartner, A. L., Jennings, D. J., ... \& Toussaint, L. (2010). Forgiveness and spirituality in organizational life: theory, status of research, and new ideas for discovery. Journal of Management, Spirituality and Religion, 7(2), 119-134. http://dx.doi.org/10.1080/14766081003765273 